\title{
Building a Website Based Gemstone Authenticity Certificate Information System
}

\section{Membangun Sistem Informasi Sertifikat Keaslian Batu Permata Berbasis Website}

\author{
Arga Pradana ${ }^{1)}$, Suprianto ${ }^{2)}$ \\ \{emp_eror_argark@ rocketmail.com ${ }^{1}$, suprianto@umsida.ac.id² $\}$
}

Program Studi Informatika, Fakultas Sains dan teknologi, Universitas Muhammadiyah Sidoarjo ${ }^{1,2}$

\begin{abstract}
In practice, the Gems Identification Laboratory (GIL) process of recording gemstone authenticity certificates is still manually and data only stored on hard disk, making it easier to create fake certificate. because the certificate can be printed by anyone, and the certificate code cannot be verified by the gemstone buyer or user, when the user buys gemstones outside the area from the Lab location. User must also send a short message to the admin to verify the authenticity of the certificate document printed by the Lab. The method used in this study uses observational data collection. The system was tested using XAMPP software. The results of this study are a website based gemstone authenticity certificate information system that can make it easier for users to check certificates anywhere by using a code that will be traced on the website without having to come to the Lab. Lab admins can also input and save certificate data in the admin menu.
\end{abstract}

Keywords : certificate; gemstone; information system; website

Abstrak- Dalam pelaksanaannya, proses pencatatan dokumen sertifikat keaslian batu yang dilakukan Gems Identification Laboratory (GIL) ini masih dilakukan secara manual dan data hanya disimpan di cakram keras, sehingga rawan terjadinya pemalsuan sertifikat. karena sertifikat dapat dicetak oleh siapapun, dan kode sertifikat juga tidak dapat di verifikasi oleh pembeli batu atau user, saat user membeli batu di luar daerah dari lokasi Lab. User juga harus mengirim pesan singkat kepada admin untuk verifikasi keaslian dokumen sertifikat yang dicetak oleh Lab. Metode yang digunakan dalam penelitian ini menggunakan pengumpulan data observasi. Pengujian dilakukan menggunakan piranti lunak XAMPP. Hasil dari penelitian ini berupa sistem informasi sertifikat keaslian batu permata berbasis website yang dapat mempermudah user untuk mengecek sertifikat dimanapun dengan menggunakan kode yang akan ditelusuri di website tanpa harus datang ke Lab. Admin Lab juga dapat menginput dan menyimpan data sertifikat dalam menu admin.

Kata kunci : sertifikat; batu permata; sistem informasi; website

\section{PENDAHULUAN}

Ilmu gemologi pada dasarnya bertujuan untuk dapat membantu masyarakat mengidentifikasi batu permata alami dan buatan. Gemologi merupakan cabang ilmu dari mineralogi. Gem Identification Laboratory (GIL) terletak di Banyuwangi, merupakan laboratorium gemological independen swasta yang khusus menerbitkan laporan berbentuk sertifikat keaslian batu mulia atau batu permata seperti safir, mirah, emerald dan chrysoberyl serta batu permata semi mulia lainnya diantaranya batu zirkon, moldavite, kuarsa, dan tanzanite. Laporan yang diterbitkan oleh GIL ada yang berupa sertifikat dan juga memo berbentuk KTP. Untuk laporan dokumen sertifikat, hasil tes keaslian dan deskripsi batu permata lebih detail dan terperinci, tetapi disesuaikan juga dengan biaya pembuatan sertifikatnya yang lebih mahal daripada memo.

Dalam pelaksanaannya, proses transaksi dan pencatatan dokumen sertifikat atau memo keaslian batu yang dilakukan GIL Banyuwangi ini masih dilakukan secara manual dan data hanya disimpan di cakram keras, sehingga rawan terjadinya pemalsuan sertifikat. karena sertifikat dapat dicetak oleh siapapun, dan kode sertifikat juga tidak dapat di verifikasi oleh pembeli batu atau user, saat user membeli batu di luar daerah dari lokasi lab atau sedang berada dimanapun.

Penyimpanan data sertifikat atau memo keaslian batu pun hanya disimpan dalam bentuk folder file sehingga akan terjadi kesulitan untuk pengolahan data. Para pelanggan pun harus mengirim pesan kepada admin dan dibalas secara manual oleh admin lab untuk verifikasi keaslian dokumen sertifikat maupun memo yang dicetak oleh Lab tersebut. Para pelanggan yang meninggalkan batunya untuk diambil keesokan harinya karena belum selesai diteliti batunya pun sering datang kembali ke tempat lab keesokan harinya namun masih belum selesai untuk pembuatan sertifikatnya.

Berdasarkan beberapa permasalahan tersebut maka penulis tertarik untuk membuat suatu sistem 
khususnya sistem informasi sertifikat keaslian batu permata dimana sistem tersebut dapat mengelola informasi keaslian kode cetak sertifikat yang sekiranya dapat mengatasi hal - hal tersebut dan juga dapat digunakan sebagai penunjang dalam kegiatan gemologi dan dapat digunakan bagi keperluan masyarakat dan penghobi batu mulia pada umumnya.

\section{A. Sistem}

\section{METODE}

Sistem adalah kumpulan dari beberapa elemen yang terkait satu dengan lainnya, dan beberapa elemen tersebut saling mempengaruhi untuk melaksanakan kegiatan bersama dalam meghasilkan tujuan atau sasaran bersama. Sebuah sistem merupakan kumpulan elemen yang saling terkait dan saling berhubungan. [9]

\section{B. Desain Sistem}

Desain sistem ini dapat menentukan bagaimana suatu sistem dapat menyelesaikan semua tahaptahap yang berhubungan dengan konfigurasi dari sebuah komponen-komponen perangkat lunak dan perangkat keras, sehingga sistem tersebut mempunyai tujuan akhir yang berupa rancang bangun sistem yang telah ditetapklan pada akhir tahap analisis system.[8]

\section{Sistem Informasi}

Sistem Informasi dapat didefinisikan menjadi beberapa bagian, diantaranya :[2]

1. Sistem buatan manusia yang terbentuk oleh beragam unsur dari suatu kelompok yang memiki sebuah hasil sebagai tampilan informasi.

2. Suatu kumpulan unsur yang ketika dilakukan pemrosesan bakal menampilkan sebuah informasi yang dibutuhkan oleh pengambil keputusan dan dapat dipakai sebagai pengendali sebuah organisasi.

3. Suatu sistem didalam suatu organisasi yang mempertemukan kebutuhan pengolahan transaksi, mendukung operasi, bersifat manajerial, dan kegiatan strategi dari suatu organisasi dan menyediakan pihak luar tertentu dengan laporan laporan yang diperlukan..

\section{Flowchart}

Flowchart merupakan sebuah urutan dari sebuah programdan diuraikan menjadi beberapa tahap dan fase sebuah program dengan cara menggambarkan secara grafik. Flowchart memiliki keuntungan yaitu mampu membantu para ahli analisis dan pemrogram komputer untuk menyelesaikan sebuah permasalahan kedalamnsegmen segmenjyang lebihjkecil dan memberikan pertolongan denganmalternatif alternative lain dalam pengoprasiannya.[1]

\section{E. Data Flow Diagram (DFD)}

Data Flow Diagram (DFD) adalah sebuah proses dari model logika yang mendeskripsikan dimana asal data ditemukan kemudian mengurai langkah berikutnya menuju ke arah data yang keluar sistem, seluruh pengolahan data kemudian disimpan, data tersebut diperoleh melalui pengolahan apa saja, berhubungan menggunakan data yang telah disimpan, dan melalui proses apa saja yang saling terkait atau yang digunakan oleh data tersebut. [4]

\section{F. Database}

Database adalah kumpulan dari data-data yang selalu berhubungan untuk menampilkan macammacam ciri dan juga tanda dengan teratur dan terstruktur melalui suatu media sebagai pendukung aplikasi di system tertentu. [10]

\section{G. Web Service}

Web service merupakan suatu teknologi pengubah kemampuan internet yang ditambahkan kemampuan web transaksional, dimana kemampuan web tersebut dapat berkomunikasi satu dengan lainnya menggunakan sebuah metode program to program (P2P). Program to user menggunakan metode business to consumer (B2C) mendominasi fokus web saat ini, namun program to program dengan interaksi business to business(B2B) akan mendominasi web transaksional.[6]

\section{H. PHP}

PHP (Hypertext Preprocessor) merupakan bahasa scripting open source yang mampu bersatu dengan format HTML untuk menghasilkan halaman website yang memiliki penampilan dinamis. Pusat server akan menjalankan beberapa perintah dan sintaks PHP karena PHP berasal dari bahasa sever side scripting kemudian hasil dari proses tersebut akan dikirimkan ke dalam web browser memakai format HTML.

PHP adalah akronim dari Personal Home Page berbentuk scripting open source yang terkandung di 
dalam HTML lalu dijalankan bersifat server side scripting. PHP berbentuk suatu kode open source yang bisa diubah dan bisa diedarkan secara leluasa. [5]

\section{My Structured Query Language (MySQL)}

MySQL merupakan suatu database yang bisa dipakai sebagai client ataupun server. MySQL dapat dioperasikan ke system operasi apapun, baik itu menggunakan Linux, Machintos, ataupun Windows. Karena MySQL mampu digunakan sebagai database server, dan mampu digunakan sebagai client maka MySQL biasa disebut juga dengan database client/server.[3]

\section{J. XAMPP}

XAMPP merupakan suatu piranti lunak webserver apache menyediakan.database server MySQL di dalamnya dan mampu untuk mensupport bahasa program PHP. Penggunaan XAMPP sebagai piranti lunak yang sangat mudah, bebas didistribusikan, dan dapat digunakan di beberapa system operasi seperti Machintos, Windows dan Linux. Sebuah nilai positif XAMPP yaitu,dengan sekali proses install maka telah disediakan bermacam modul diantaranya : ApacheeWeb Server, MySQL Database, dan dukungan PHP seperti PHP5 dan PHP 7.[7]

\section{HASIL DAN PEMBAHASAN}

\section{A. Lokasi dan Waktu Penelitian}

Dalam menyelesaikan penelitian ini, penulis melakukan penelitian dan pengumpulan data pada Gems Identification Laboratory (GIL) yang beralamat di Jl. Kolonel Sugiono No. 41, Banyuwangi, Jawa Timur. Penelitian dimulai pada tanggal 10 Desember 2020 hingga 10 Januari 2021.

\section{B. Bahan dan Alat Penelitian}

Adapun bahan dan alat yang akan digunakan dalam penelitian ini adalah sebagai berikut :

a. Bahan Penelitian

Bahan - bahan yang akan digunakan dalam penelitian ini antara lain data hasil spesifikasi barang yang telah didapat saat melakukan penelitian.

b. Alat Penelitian

Alat yang digunakan dalam penelitian ini adalah sebagai berikut :

1. Hardware

1. Processor : Intel ${ }^{\circledR}$ Core $^{\mathrm{TM}} \mathrm{i} 7-7700 \mathrm{HQ}$ CPU @ $2.80 \mathrm{GHz}$

2. Memory : $16 \mathrm{~GB}$

3. Motherboard : Asus

4. Harddisk : $1 \mathrm{~TB}$

2. Software

1. Microsoft Windows 10 Home Single Language sebagai Operasi Sistem yang digunakan untuk menjalankan Aplikasi.

2. Adobe Dreamweaver CC 2018.

3. XAMPP v3.2.2

\section{Teknik Pengumpulan Data}

Teknik pengumpulan data yang digunakan dalam penelitian ini adalah sebagai berikut :

a. Observasi.

Teknik pengumpulan data dengan mengadakan penelitian dan peninjauan langsung pada Gems Identifiation Laboratory terhadap permasalahan penyebaran informasi yang ada.

b. Interview.

Mewawancarai atau menanyakan beberapa permasalahan kepada para ahli terkait obyek penelitian untuk medapat jawaban yang tepat sasaran dan juga relevan dengan permasalahan yang ada. Disini penulis melakukan wawancara kepada Pemilik GIL sekaligus ahli gemologi.

\section{Pembuatan Sistem Informasi}

Sistem Informasi Sertifikat Keaslian Batu Permata pada penelitian ini dibangun menggunakan PHP yang berjalan di Sistem Operasi Windows 10. Implementasi yang dilakukan pada sistem ini adalah sebuah sistem yang dapat memberikan informasi mengenai informasi-informasi penting dan terbaru dari Laboratorium Gemologi yang terkait dengan informasi keaslian sertifikat batu permata dan sebagai sarana penyampaian kritik dan saran.

1. Sistem Informasi Sertifikat Keaslian Batu Permata yang akan dibuat menggunakan model client server sehingga langkah awal adalah membuat database untuk penyimpanan imformasi, karena data-data yang akan di akses berasal dari database MySql.

2. Memulai penulisan kode program dengan bahasa pemrograman PHP. Yang pertama dibuat adalah halaman PHP untuk menjalankan sistem dan untuk mengakses database. 


\section{E. Flowchart Alur Kerja Sistem}

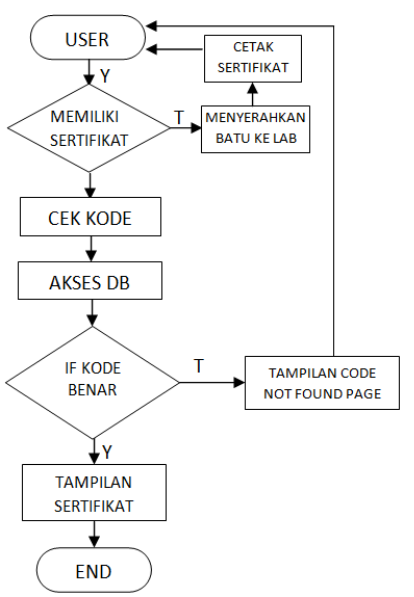

Gambar 3.5 Flowchart Alur Kerja Sistem

Penjelasan dari gambar alur kerja sistem diatas yaitu User jika belum memiliki sertifikat maka menyerahkan batu permata dulu ke petugas lab, kemudian petugas lab akan mencetak sertifikat sesuai spesifikasi batu yang telah diidentifikasi. Jika telah memiliki sertifikat, maka user dapat menginputkan kode sertifikat, kemudian sistem mengecek kode sertifikat di database, jika kode ditemukan di database maka user akan menerima semua informasi terkait kode sertifikat tersebut. Jika kode tidak ditemukan, maka akan muncul halaman kode tidak tidak ditemukan, dan user akan mengulang untuk menginput kode sertifikat kembali.

\section{F. Data Flow Diagram (DFD)}

Berikut ini penjelasan DFD fungsional Admin dan User.

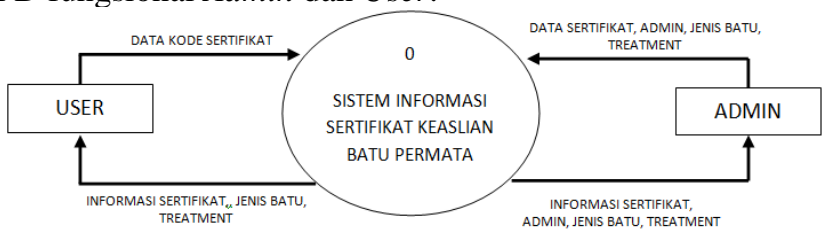

Gambar 3.6.1 DFD Level 0

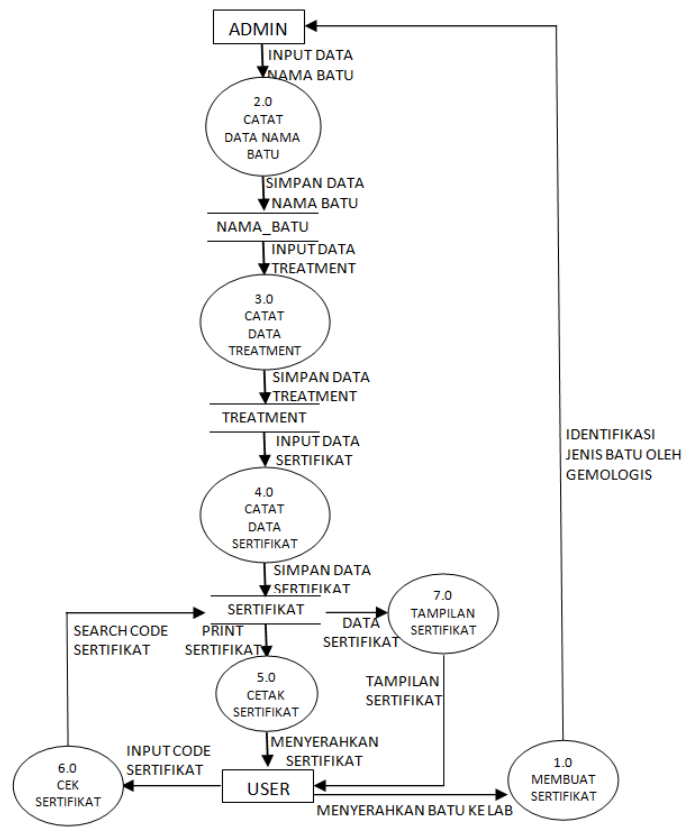

Gambar 3.6.2 DFD Level 1 


\section{G. Relasi Antar Tabel}

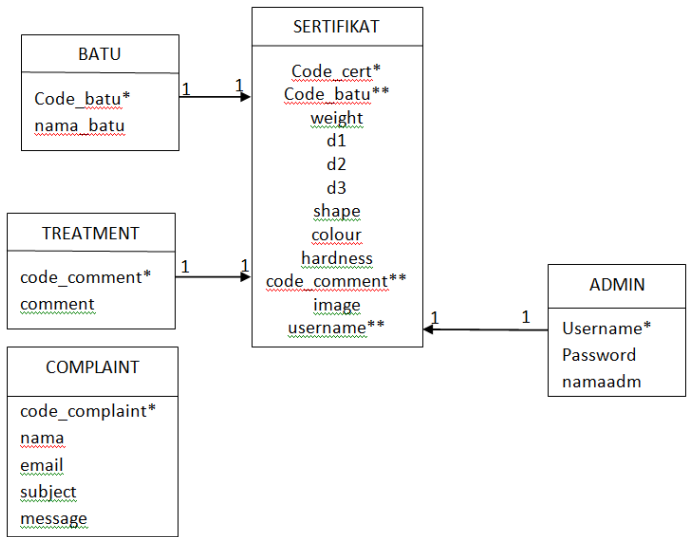

$$
\begin{array}{ccc} 
& \multicolumn{3}{l}{\text { Keterangan: }} \\
* & = & \text { Primary Key } \\
* * & = & \text { Foreign Key }
\end{array}
$$

Gambar 3.7. Relasi Antar Tabel

\section{H. Pembahasan}

Pada sistem informasi ini menyediakan beberapa fitur diantaranya : login, home, data admin, data nama batu, data comment, data sertifikat, kritik dan saran, serta log out.

\section{Implementasi Sistem}

Pada bab ini akan dilakukan bagian pengujian dari sistem program, serta beberapa hal yang akan terjadi ketika proses berlangsung. Sebelum melaksanakan pengujian, terdapat hal-hal yang perlu diperhatikan, terutama bagian perangkat lunak Adobe Dreamweaver CC 2018 sebagai penyunting text bahasa pemrograman PHP dan XAMPP untuk web servernya.

\section{Halaman Utama User}

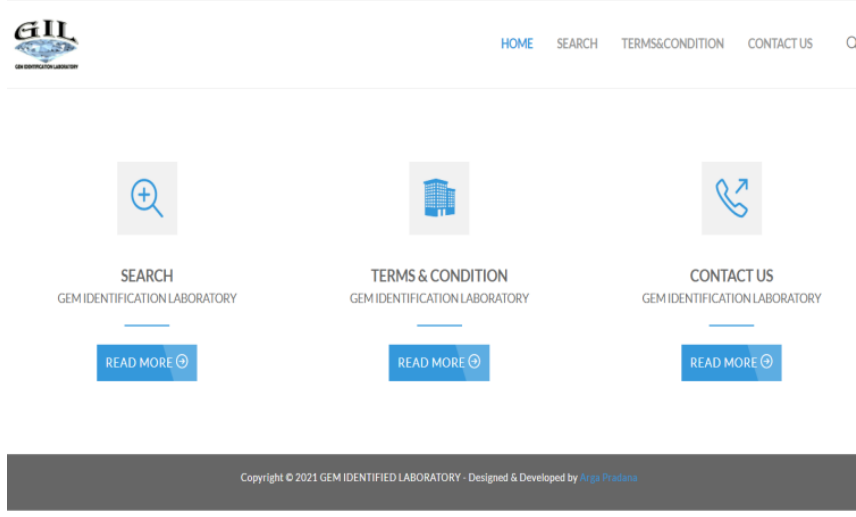

Gambar 3.8 Tampilan Halaman User

Pada halaman ini terdapat pilihan menu search untuk melacak kode sertifikat user, terms\&condition untuk menampilkan informasi syarat dan ketentuan berlaku terkait sertifikat keaslian batu permata, dan, contact us untuk menampilkan formulir kontak agar user dapat menghubungi pihak lab maupun sekedar memberikan kritik dan saran. TERMS\& CONDITION

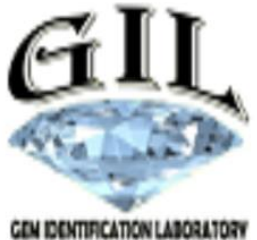




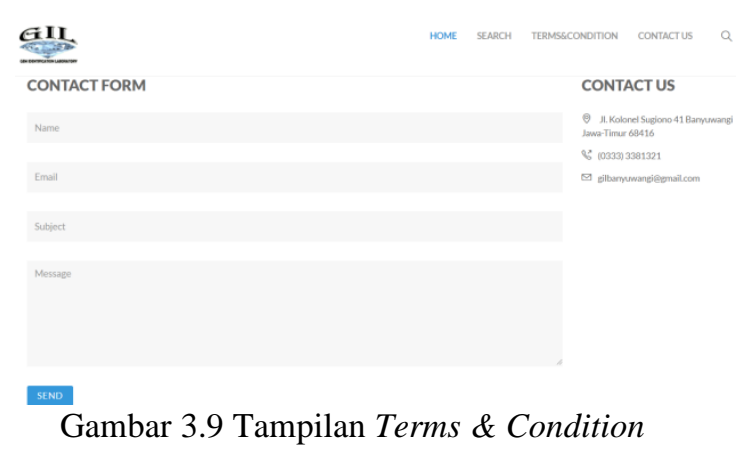

2. Pencarian Sertifikat / Search

GIl

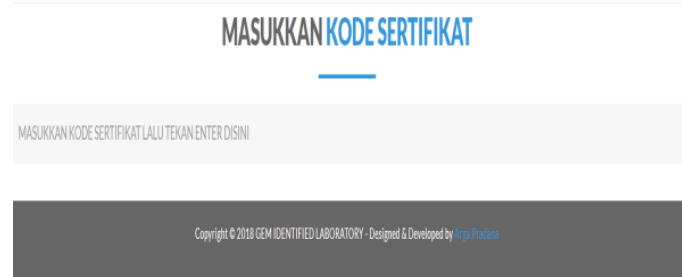

DETAIL REPORT CHECK LABORATORY

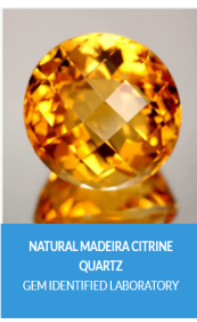

Gambar 3.11 Tampilan Menu Search
Gambar 3.10 Tampilan Contact Us

Halaman tampilan search atau pelacakan kode sertifikat terdapat satu buah formulir untuk memasukkan kode sertifikat. Setelah kode dimasukkan dan User menekan tombol keyboard enter, maka dihalaman ini akan muncul seluruh informasi sertifikat sesuai dengan nomor kode yang telah dimasukkan. User dapat mencocokkan sertifikat yang dipegang oleh User dengan basis data dari lab batu permata apakah seluruh informasinya sesuai atau tidak, agar User tidak tertipu oleh sertifikat palsu ketika membeli batu permata.

\section{Halaman Utama Admin}

Halaman login merupakan sebuah tampilan utama dalam sebuah sistem, kita harus login

terlebih dahulu jika ingin masuk ke halaman selanjutnya.

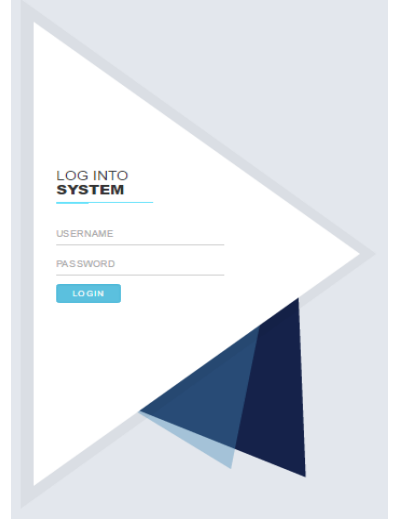



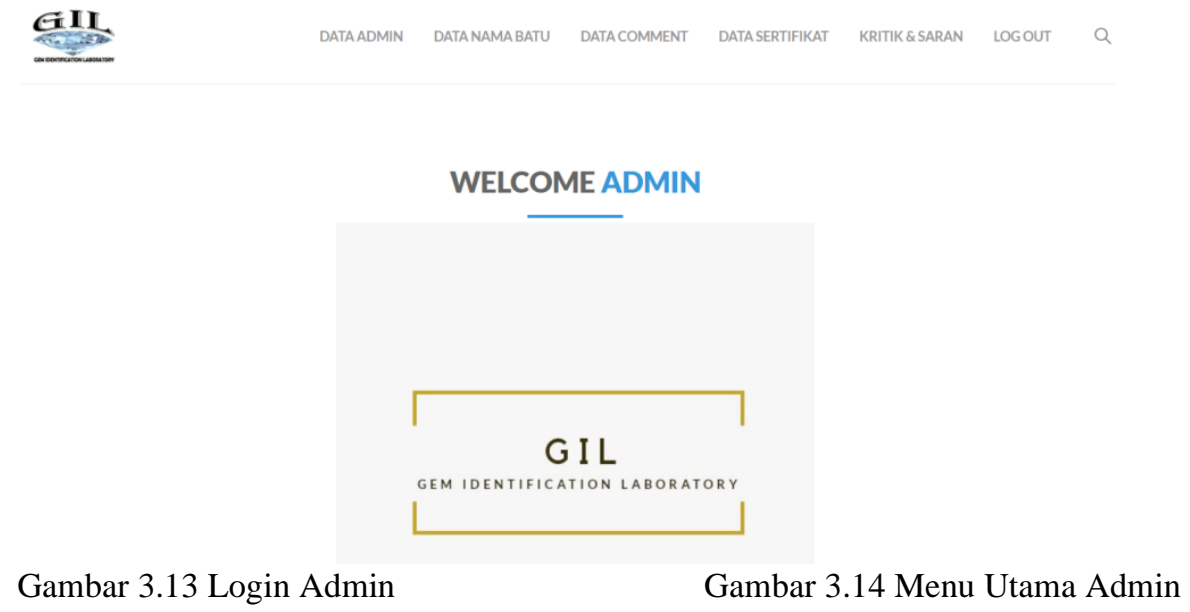

Menu utama admin digunakan untuk menginputkan, mengedit dan menghapus data informasi tentang data admin dan data sertifikat batu permata. Didalam menu ini terdapat enam submenu diantaranya :

a) Data admin digunakan untuk input, edit dan hapus data admin.

b) Data Nama Batu digunakan untuk input, edit, dan hapus data Nama Jenis Batu Permata.

c) Data Comment digunakan untuk input, edit, dan hapus data Nama Jenis Treatment Batu Permata.

d) Data Sertifikat digunakan untuk input, edit, dan hapus data Sertifikat Keaslian Batu Permata.

e) Data Kritik \& Saran digunakan untuk view, reply, edit, dan hapus data keluhan, kritik, dan saran.

f) Menu Keluar digunakan untuk keluar dari menu admin.

\section{Menu Data Sertifikat}

\section{DATASERTIFIKAT GIL(GEM INDENTIFICATION LABORATORY)}
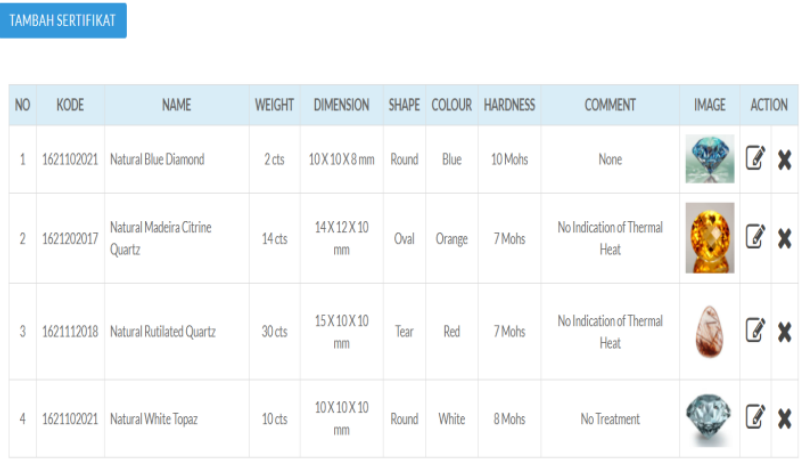

INPUT DATA SERTIFIKAT

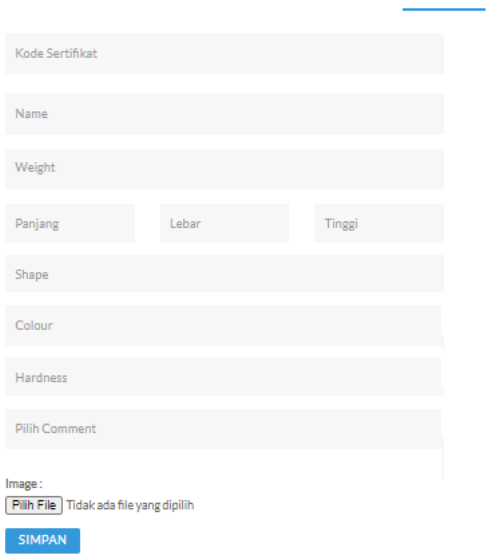

Gambar 3.15 Menu Data Sertifikat

Gambar 3.16 Input Data Sertifikat

Pada halaman data sertifikat terdapat tabel yang isinya meliputi kode, name, weight, 
dimension, shape, colour, hardness, comment dan image. Ketika tombol tambah sertifikat di klik maka akan muncul halaman input data sertifikat. Pada halaman input data sertifikat terdapat form yang berisikan input kode sertifikat, name, weight, panjang, lebar, tinggi, shape, colour, hardness, comment, dan image. Serta terdapat tombol simpan.

\section{KESIMPULAN}

Dari hasil penelitian dapat disimpulkan sebagai berikut:

1. Sistem ini dapat membantu admin untuk mengetahui detail data admin, data batu, data sertifikat, dan juga untuk mengingatkan pelayanan melalui fitur kritik dan saran.

2. Biaya untuk mendapatkan informasi melalui situs website lebih hemat dan murah dibandingkan menggunakan telepon.

\section{UCAPAN TERIMA KASIH}

Dengan demikian, pada kesempatan kali ini izinkan saya sebagai penulis untuk mengahturkan terimakasih dan penghargaan yang sebesar sebesarnya kepada :

1. Dr. Hidayatulloh, M.Si Rektor Universitas Muhammadiyah Sidoarjo.

2. Dr. Hindarto, S.Kom., MT selaku Dekan Fakultas Sains dan Teknologi Universitas Muhammadiyah Sidoarjo.

3. Ir. Sumarno, MM selaku Kaprodi Informatika Universitas Muhammadiyah Sidoarjo.

4. Dr. Suprianto, S.Si., M.Si. selaku Dosen Pembimbing dalam menyelesaikan penelitian ini. Telah memberikan saran-saran perbaikan, pengetahuan dan dorongan dalam penyelesaian penelitian penulis.

5. Ribangun B. Jakaria, ST., MM selaku Dosen Wali Kelas Informatika Fakultas Sains dan Teknologi Universitas Muhammadiyah Sidoarjo.

6. Orang Tua dan Kakak serta Adik yang selalu mendukung penulis dengan setulus hati baik secara moril maupun spiritual

7. Teman-teman Universitas seperjuangan terima kasih atas kerjasamanya.

\section{REFERENSI}

[1] Adelia, dan Jimmy Setiawan., "Implementasi Customer Relationship Management (CRM) pada Sistem Reservasi Hotel berbasisi Website dan Desktop," Bandung: Universitas Kristen Maranatha. Vol. 6, No. 2, September, 113-126, 2011..

[2] Afyenni, R, "Perancangan Data Flow Diagram Untuk Sistem Informasi Sekolah," TEKNOIF, Vol. 2 No., 13, 2014.

[3] Al-Bahra bin Ladjamudin., "Analisis dan Desain Sistem Informasi," Graha Ilmu, Yogyakarta, 2005.

[4] Andri Kristanto, "Perancangan Sistem Informasi dan Aplikasinya," Gava Media, Yogyakarta, 2008.

[5] Bunafit, Nugroho, "Membuat Aplikasi Sistem Pakar dengan PHP dan MySQL dengan Editor Dreamweaver," Ardana Media, Yogyakarta, 2006.

[6] Deviana, Hartati, "Penerapan XML Web service Pada Sistem Distribusi Barang," Jurnal Generic. 6. 61-70, 2011.

[7] Herny Februariyanti dan Eri Zuliarso, "Rancang Bangun Sistem Perpustakaan untuk Jurnal Elektronik," Vol. 17, No.2, Juli 2012.

[8] Jogiyanto, H.M., "Analisa dan Desain Sistem Informasi: Pendekatan Terstruktur Teori dan Praktik Aplikasi Bisnis," Andi, Yogyakarta, 2005.

[9] O’Brien, A James and George M Marakas., "Analisa Sistem Informasi/Tata Sutabri," Ed I, Andy, Yogyakarta.

[10] Minarni., dan Susanti., "Sistem Informasi Inventory Obat pada Rumah Sakit Umum Daerah Padang," Volume 16, No.1, 2014. 